\title{
DETERMINATION OF OPTIMUM ELECTROLYTE COMPOSITION FOR MOLTEN CARBONATE FUEL CELLS
}

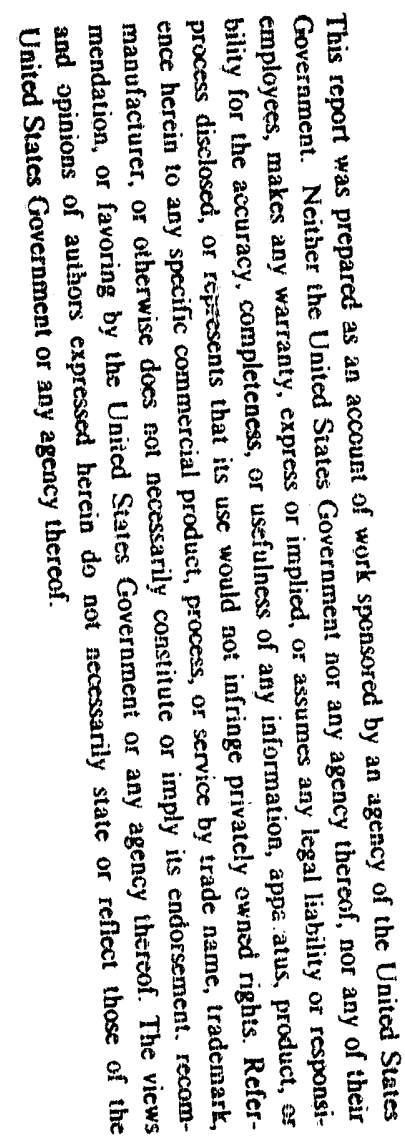

QUARTERLY TECHNICAL PROGRESS REPORT *

October - December, 1987 "

Prepared by

ENERGY RESEARCH CORPORATION

3 Great pasture Road

Danbury, CT 06813

Principal Investigators

C.Y. Yuh

A. Pigeaud

Prepared For

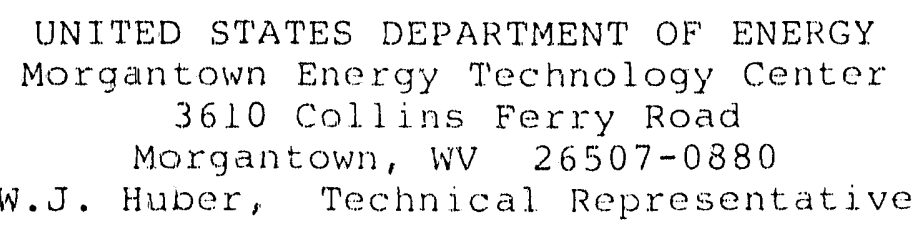

Work Performed under Contract No. DE-AC21-86MC23264
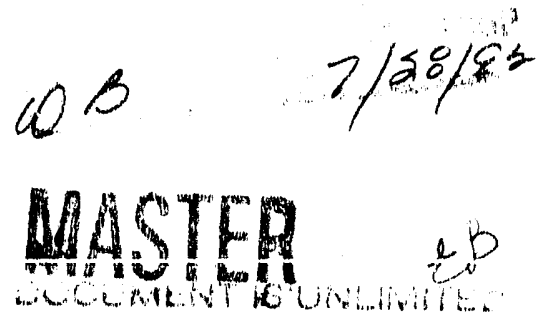
NOT ICE

This report was prepared as an account of work sponsored by an agency of the United States Government. Neither the United States nor any agency, thereof, nor any of its employees, nor any of its contractors, subcontractors, or their employees, makes any warranty, expressed or irplied, or assumes any legal liability or responsibility for any third party's use or the results of such use of any information, apparatus, product or process disclosed in this report or represents that its use by such thind party would not infringe privately owied rights. 
TITLE:

CONTRACT NO.:

CONTRACTOR:
DETERMINATION OF OPTIMUM ELECTROLYTE COMPOSITION FOR MOLTEN CARBONATE FUEL CELL
$D E-A C 21-86 M C 23264$

Energy Research Corp. 3 Great Pasture Road Danbury, CT $068 \cdot 3$

CONTRACT PERIOD: October 1,1986 to september 30,1988

OBJECTIVE: The objective of this study is to determine the optimum electrolyte composition for molten carbonate fuel celis. To accomplish this, the contractor will provide:

1. Comprehensive reports of on-going efforts to optimize carbonate composition.

2. A list of characteristics affected by electrolyte composition variations; e.g. ionic conductivity, vapor pressure, melting range, gas solubility, exchange current densities on Nio, corrosion and cathode dissolution effects.

3. Assessment of the overall effects that these characteristics have on stateof-the-art cell voltage and lifetime.

\section{CONTRACT TASKS:}

Task 1. Preparation of Management Plan.

Task 2. Literature survey to review completed and ongoing efforts to optimize MCFC electrolyte composition.

Task 3. Electrolyte Composition screening to define "Optimum" in terms of carbonate properties and fuel cell parameters.

Task 4. Test plan submission describing methods to be used for identifying and verifying the optimum composition criteria.

Task 5. Experimental Determination of Optimum Electrolytes by a variety of out-of-cell and in-cell tests. 
PROGRESS BY TASK

\section{TASK 2 LITERATURE SURVEY}

The minor effort under this task to continue surveying the literature for relevant information pertaining to composition effects on MCFC performance and material endurance have resulted in the folowing items. The basicity of alkali carbonate mixtures at $910^{\circ} \mathrm{C}$ has been measured by shores(66) with an electrochemical cell measuring $O^{=}$ion activity. The experimental values were found to agree with previously calculated ones. This paper thus proves that lia content can effectively increase melt basicity, which in turn should decrease Nio solubility.

Uchida and Nishina(67) performed a thermodynamic analysis of alkali carbonate mixtures and proposed that the superoxide mechanism is predominant in $\mathrm{Li} / K$ and $\mathrm{Na} / \mathrm{K}$ eutcotic melts whereas the peroxide mechanism is dominant in the Li/Na eutectic melt. In the ternary eutectic melt, oxygen reduction is under mixed control of superoxide and peroxide paths. This conclusion is agreed upon by many researchers, as discussed in the Topical Report submitted in April, 1987.

Iwase, et al. (68) have also used the AC-impedance method to study a porous NiO electrode filled with different amounts of $\mathrm{L} i / \mathrm{K}$ electrolyte. In this work they have demonstrated the feasibility of using the technique for cathode performance studies. Also, since it is shown that variation in electrolyte fill-level has a definite effect on performance, careful electrolyte impregnation and post-test fill-level determinations are planned for our experiments to be certain that only effects of electrolyte composition are measured. 
Ogawa et al.(69) have studied the effect of alkaline earth additives (Mg, Ca, Sr, Ba carbonates) on the dissolution behavior of Nio cathodes in $10-\mathrm{cm}^{2}, 1 a b-s c a l e$ fuel cells. The amount of Nio-dissolution was found to decrease by a factor of $1 / 2$ to $1 / 3$ with 5 moleo additions of $\mathrm{CaCO}_{3}, \mathrm{SrCO}_{3}$, and $\mathrm{BaCO}_{3}$, which is roughly in agreement with most of ERC's findings. Furthermore, the ivio loss was found to be proportional to the period of operation and to the partial pressure of $\mathrm{CO}_{2}$ in the oxidant, also in agreement with ERC's findings. The above results therefore confirm the general approach of using alkaline earth additives to suppress NiO dissolution. However, the effect of the different additives (i.e. Ca, Sr, Ba carbonate) coula not be accurately differentiated, probably due to the usual difficulties with sampling and ppm. analytical techniques. Also, Ni transport rate and tho mode of remprecipitation or crystallization toward the anode may be just as important as the Nio equilibrium solubility itself. Therefore, eguilibrium solubility alone may not bo ontirely indicative of overall cathode loss rate or the ultimate effect it has on fuel cell performance.

Sato, et al. (70) have studied the interaction between Li/K. melts and LiAlOz and have found that both stable and metastable solid carbonate phases exist. Furthermore, the melting points of these phases are affected by the presence or absence of LiAlOz. Therefore, the Li/K carbonate phase diagram appears more complicated than what was originally thought. This phenomenon may influence the start-up or thermal-cycle behavior of cells and stacks and may, in particular, have to be taken into account with stack testing. 


\section{TASK 3 ELECTROLYTE COMPOSITION SCREENING}

This task, which was completed last August following the literature search and data evaluation phase of the work, resulted in a master table which lists the most important electrolyte properties that were then considered to have a definite effect on fuel cell performance. However, the detailed information and precise quantitative data for accurately comparing performance and endurance behavior were for the most part not yet available. At this time with more data, the table can be updated especialiy with respect to the carbonate characteristics that are of primary importance: i.e. Nio-solubility which affects cathode losses and 3105 corrosion which affects long-term hardware stability. What follows is a review of this updated master table in connection with the Interim program Evaluation which is a recuirement in our wolk schedule at about this time.

\subsection{INTERIM EVALUATION}

This section presents the revised summary of the 8 candidate electrolyte properties with respect to the most important fuel cell characteristics to be considered. Discussion of the detailed data for Table 3.1 and the derived out-of-cell correlations that have been used will be presented under Task 5. The melting points and conductivity differences between candidate melts have not greatly changed. Additional data trom recent literature has confirmed these values and except for some slight changes that might occur in the estimated values when a small amount of additive is present, these properties are not in doubt. 
All candidate compositions except for the high lithium, off-eutectic, Li/K mixture $\left(S_{L}\right)$ have melting points at least $100^{\circ} \mathrm{C}$ below the $M C F C$ operating temperature. The high lithium $S_{L}$ composition has therefore a aisadvantage here which could have some effect on uniform carbonate distribution upon start-up. In connection with cell resistance, it is clear that the slightly off- eutectic sodium blend has an advantage in providing up to $60 \%$ higher ionic conductivity than the present standard blends. One of the advantages for the sodium blend $\left(\mathbb{N}_{L}\right)$, therefore, is that it may lower the electrolyte contribution to a fuel cell's internal resistances both in the electrodes and in the matrix.

Theoretical predictions of electrolyte basicity affecting Nio-solubility have been confirmed by sets of duplicate nickel solubility measurements, as will be further discussed. Measured solubilities for each electrolyte were then correlated using a cathode, standard-rate-of-loss, conversion that has been derived from recently documented colls. From the latter values shown in Table 3.1 , it is evident that tho sodium blend (i.e. $\mathrm{N}_{\mathrm{L}}$, with the most alkaline electrolyte composition) should also be the most effective in limiting cathode electrode loss. By calculation, it may be estimated that the cumulative loss in 40,000 hours of operation with the sodium containing electrolyte will be $\sim 52 \mathrm{mg} / \mathrm{cm}^{2}$ for a typical cathode of nominally $200 \mathrm{mg} / \mathrm{cm}^{2}$ nickel oxide. Hence, about: $25 \%$ of original cathode weight could be transfered, which as far as our limited experience goe is accoptable for such an extended period of operation. 


\begin{tabular}{|c|c|c|c|c|c|c|c|}
\hline 岕 & 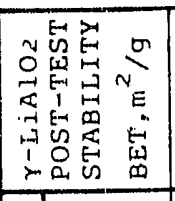 & $\stackrel{*}{n}$ & in & * & * & * & $\stackrel{\text { In }}{\wedge}$ \\
\hline 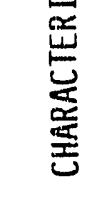 & 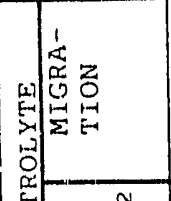 & * & 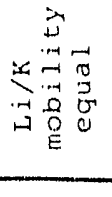 & * & * & * & 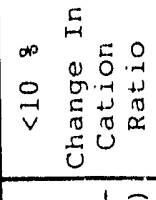 \\
\hline 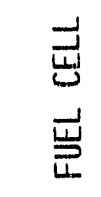 & 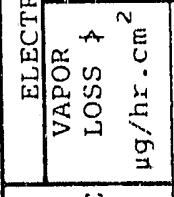 & ñ. & $\begin{array}{l}\sigma \\
\dot{0}\end{array}$ & $\underset{0}{\dddot{0}}$ & in & $\begin{array}{l}\stackrel{n}{n} \\
\stackrel{0}{0}\end{array}$ & 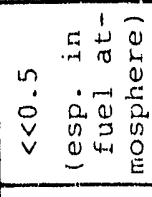 \\
\hline $\begin{array}{l}\text { U } \\
\text { 总 } \\
\text { 皇 }\end{array}$ & 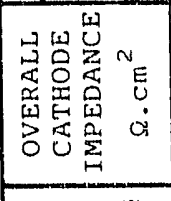 & * & * & * & * & * & $\begin{array}{l}q \\
\dot{p}\end{array}$ \\
\hline 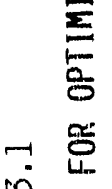 & 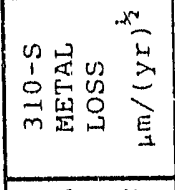 & ल) & $\stackrel{\infty}{\sim}$ & $\stackrel{\sim}{N}$ & $\vec{m}$ & $\tilde{m}$ & 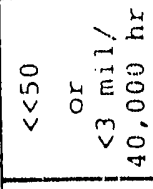 \\
\hline 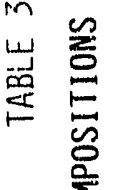 & 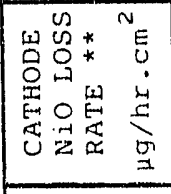 & $\stackrel{n}{\dot{m}}$ & $\stackrel{\stackrel{i}{N}}{ }$ & $\stackrel{m}{i}$ & $\because$ & $\stackrel{n}{\sim}$ & $\dot{v}$ \\
\hline 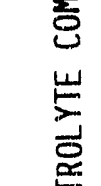 & 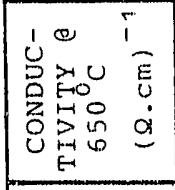 & $\stackrel{r}{-}$ & $\ddot{\sim}$ & $\stackrel{m}{i}$ & $\begin{array}{l}* \\
\stackrel{+}{-}\end{array}$ & $\stackrel{*}{*} \stackrel{+}{-}$ & $\stackrel{\ddot{\sim}}{\stackrel{\sim}{\wedge}}$ \\
\hline $\begin{array}{l}\text { 出 } \\
\text { 㞾 }\end{array}$ & 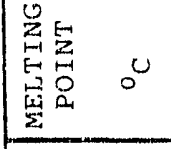 & 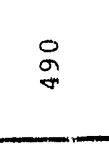 & $\stackrel{n}{n}$ & 年 & $\begin{array}{l}* \\
\stackrel{0}{0} \\
\sigma \\
\sigma\end{array}$ & 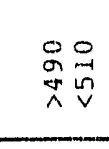 & 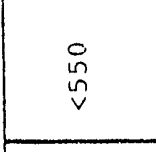 \\
\hline 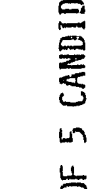 & 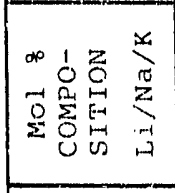 & 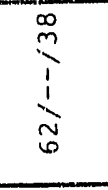 & 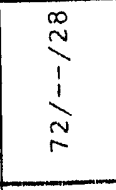 & $\begin{array}{l}1 \\
1 \\
0 \\
0 \\
0 \\
0\end{array}$ & 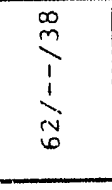 & $\begin{array}{l}0 \\
⿱ \\
1 \\
\text { के } \\
\text { जे }\end{array}$ & \\
\hline 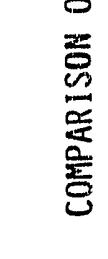 & 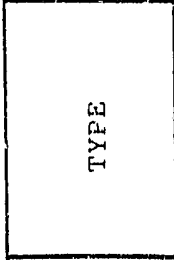 & 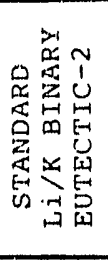 & 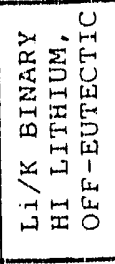 & 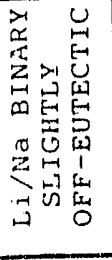 & 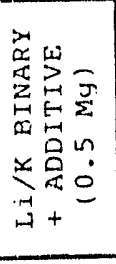 & 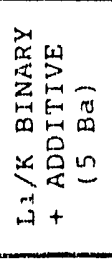 & 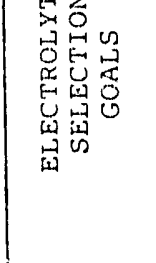 \\
\hline & UO口W & $\infty$ & $w^{2}$ & $z_{1}^{-7}$ & $n^{\Sigma}$ & $0^{x}$ & \\
\hline
\end{tabular}


In connection with corrosion, the major concern of greater hardware attack in the presence of sodium containing blends has been proven incorrect as far as our present work is concerned. When comparing the amount of attack on the superior $310 \mathrm{~s}$ type of stainless steel used, there is very little variation in corrosion due to the different candidate electrolyte compositions. If anything can be concluded, it is that the 60Li/40 va blend, $\mathrm{N}_{L}$, even shows a somewhat lower potential for corrosion than the standard $62 \mathrm{Li} / 38 \mathrm{~K}$ carbonate composition. On the other hand none of the candidate electrolytes, even when tested up to 3000 hours using accelerated exposure with higher than usual temperature anu humidity conditions, have resulted in any kind of serious corrosion projections. For the $\mathrm{N}_{\mathrm{L}}$ blend, the low metal losis rate noted of $29 \mu \mathrm{m} /(\mathrm{yr})^{\frac{1}{2}}$ translates to approximately $2.4 \mathrm{mil}$ of metal loss due to corrosion in 40,000 hours which is probably acceptable for haraware materials of average $10 \mathrm{mil}$ thickness. Furthermore, the maximum corrosion penetration into the steel at a few sites is a median of somewhat less than $3.5 \mathrm{x}$ the average metal loss depth and thus catastrophic leakage across any gas separating membrane also appears unlikely.

Thus, the fact that melt composition does not strongly bear on corrosion differences, allows this primary factor for optimization to be eliminated, making Nio dissolution the major selection criterion. From this summary of recent data, it can therefore be concluded that a definite optimization of primary electrolyte characteristics can be achieved. The best candidate mixture for the upcoming bench-scale phase of testing is therefore the $\mathrm{N}_{L}$ blend with the other composition being the standard comparison electrolyte. Eventhough not all of the out-of-cell experiments are complete, it has been necessary for the present schedule to make this decision 


\section{ENERGY RESEARCH CORPOAATION}

because a good deal of preparatory work (e.g. electrolyte filling of the components for the first set of four bench-scale cells) is already in progress. This important selection has therefore been made in as much as adequate corrosion behavior as well as the lowest Nio solubility were found with this melt. Other advantages which also contributed to this decision were that the $\mathrm{N}_{\mathrm{L}}$ blend has the highest conductivity of any of the candidate compositions and, in the absence of potassium carbonate, the melt will have lower electrolyte volatility on the anode side of the cell. Lower ohmic loss and therefore a somewhat better overall performance and better performance endurance due to less electrolyte being transfered are the additional expected benefits for this melt over the standard $62 \mathrm{Li} / 33 \mathrm{~K}$ carbonate mixture.

Although alkaline-earth additives such as $\mathrm{MgCO}_{3}$ reduce the Nio-solubility to some extent, this does not provide a very large advangtage for the $S_{M}$ blend which has otherwise nothing special to add. There is also the concern that the very small quantity of $\mathrm{MgCO}_{3}$ which can only dissolve in a carbonate melt will easily deplete and hence may only have a short-term effect. Moreover, it has been found in recent ERC bench-scale cells that the recrystallizaton habit of transferred nickel being reduced in the matrix can be quite unusual when the electrolyte contains $\mathrm{BaCO}_{3}$ additive (i.e. dendritic shaped nickel crystals appear to form). This could eventually cause cell short-circuiting across the matrix and hence appears to argue against the use of additives for the present. Some thought is being given, however, to combining magnesium carbonate with sodium-containing blends to possibly further suppress Nio-solubility in the already optimized composition. Such a test might be recommended for the 5000 hour bench-scale cells to be operated when the present 1000-hour tests are complete. 


\section{TASK 5 EXPERIMENTAL DETERMINATION OF ELECTROLYTE PROPERTIES}

During this quarter, corrosion testing of $310 \mathrm{~s}$ stainless steel in the 5 candidate electrolytes was completed. Coupons were cross-sectioned and metallographically examined for metal loss rates and maximum corrosion penetration. The Nio-solubility study which consists of high precision analytical determinations of dissolved nickel in the candidate melts is also essentially finished. Cathode performance and LiAloz-stability experiments are in progress, while the electrolyte migration experiments and bench-scale cell testing are being prepared.

\subsection{CORROSION}

Corrosion testing of $310 \mathrm{~s}$ stainless steel coupons for 500 and 3000 hour periods in the five candidate electrolytes has been completed. A number of conclusions from observations and micrographs were reported in the october and November monthly reports which will be summarized below. The treatment of post-test coupons by washing and cross-sectioning for metallographic analysis has already been described in detail in earlier reports.

The corrosion rate of $310 \mathrm{~s}$ in the five candidate melts were measured by high definition optical microscopy and compared in terms of both the maximum depth of corrosion attack and the average amount of metal loss with respect to the original coupon surface. Since these measurements vary depending on the location of corrosion attack upon the specimen surface, median rates were determined by averaging the general corrosion depths and metal losses at many points on the coupons. It is suggested that the non-uniform corrosion is caused primarily by the originally non-uniform distribution of carbonate on the coupons' surfaces and possibly also by shielding of areas under the electrode plaque where the electrolyte is injtially stored inside the u-bend coupons. 


\section{ENERGY RESEARCH CORPORATION}

Summary Figures 5.1 and 5.2 show that this average corrosion and maximum depth of attack due to molten alkali carbonate on $310 \mathrm{~s}$ stainless steel results in only minor differences between the five candidate melt compositions. This holds both after 500 and 3000 hours of duplicate tests under exactly the same temperature and humidity conditions $\left(700^{\circ} \mathrm{C}\right.$ and $\left.5 \% \mathrm{HzO}\right)$. significantly, these differences between the melts, in fact, should be small if corrosion and the subsequent stability of the protective scales are primarily a function of melt alkalinity. This will be the case when the solubilities of LiFeOz and $\mathrm{Li} 2 \mathrm{CrO}_{4}$ - i.e. the major constituents of the protective outer scales on stainless steel(72) - are the main determining factors for scale stability. The oxides exist in equilibrium with their corresponding ions in solution, such as $\mathrm{Li}^{+}, \mathrm{Fe}^{3+}$, $\mathrm{Cr}^{6+}, \mathrm{O}^{=}$, etc. Hence solubility must clearly be a function of the local metal ion, and also the oxygen ion $\left(\mathrm{O}^{=}\right)$, concentrations. Thus, electrolyte basicity in terms of $0^{-=}$at the metal surface is an important parameter.

However, it may be assumed because of the generally low absolute magnitude of $\mathrm{O}^{=}$ion concentration in carbonate electrolyte, that the slight differences in basicity which occur between the different melt compositions are probably insufficient to cause a major variation in corrosion attack. The average metal loss and maximum attack depth due to corrosion are seen to be rather insensitive to melt basicity; for the crosssections of the 5 candidate melts over a 500 hour period these parameters are approximately 7.4 and $30 \mu m$. If corrosion rates may be assumed to be parabolic with time, this represents a general metal loss rate of $31 \mu \mathrm{m} /(\mathrm{yr})^{\frac{1}{2}}$. similarly, average metal losses and maximum depth of attack found in the 3000 hour tests are approximately 18 and $58 \mathrm{\mu m}$, respectively. This translates into a general metal loss rate of $30.7 \mu \mathrm{m} /(\mathrm{yr}$. which is very close to that previously calculated for the 500 hour period of testing. The assumed parabolic corrosion behavior is thus also confirmed from these tests. 


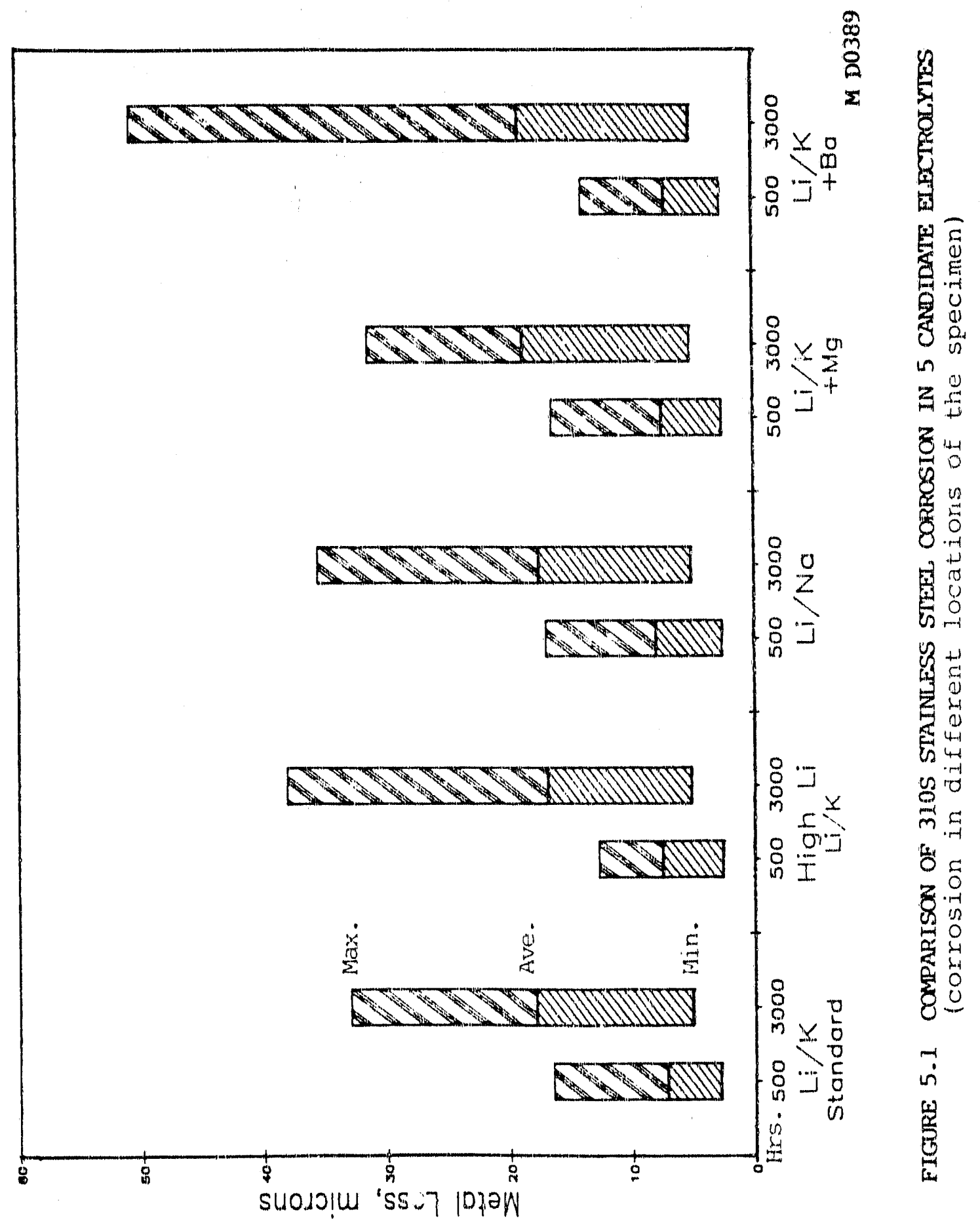




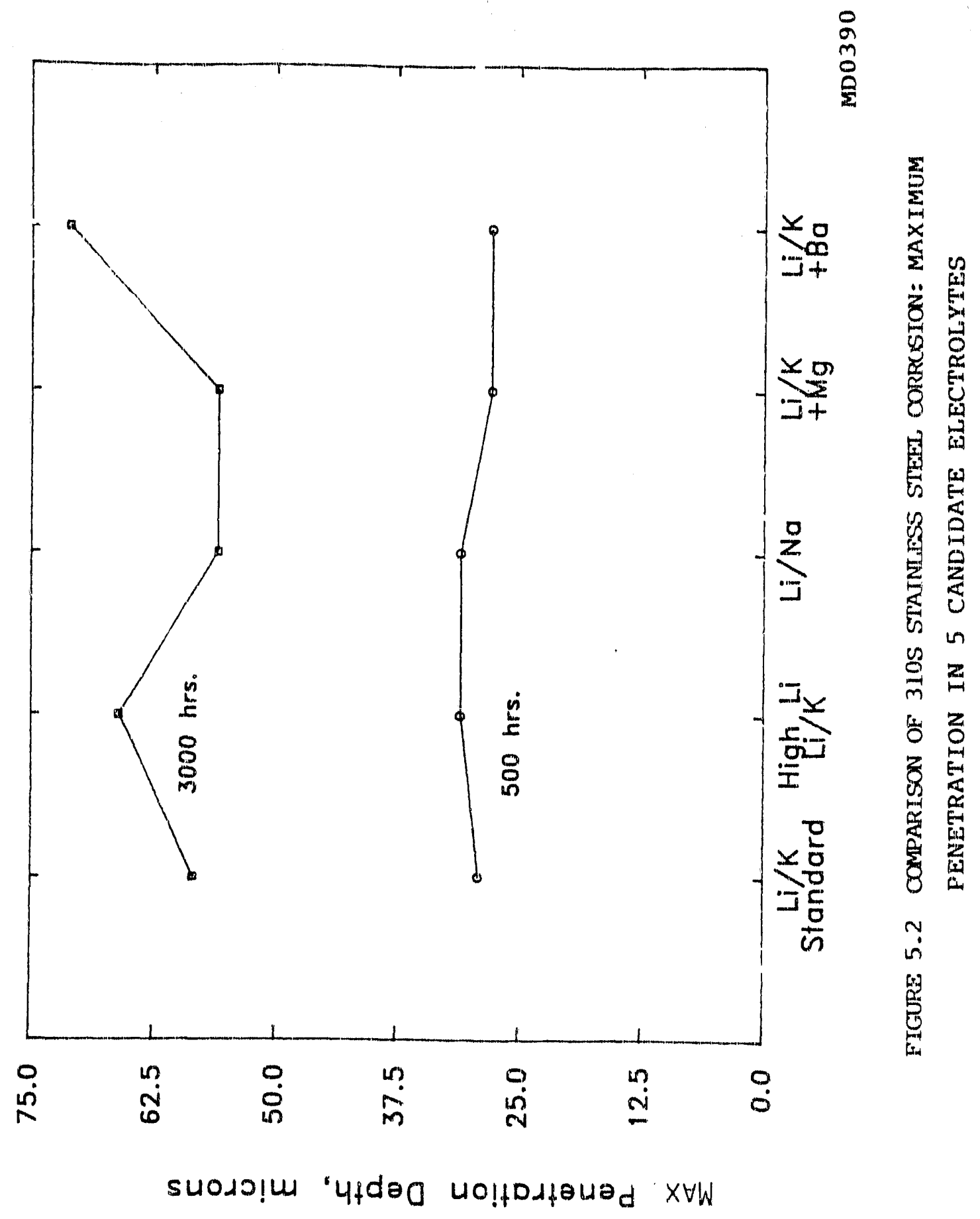


ENERGY RIESEARCH COAPORATION

In general, it appears that the scale on the top surfaces of the cross-sections (i.e. facing the inside of the U-bend coupons) are slightly thicker in the case of the sodium melt, but when considering the bottom surfaces they are thicker in the case of the potassium melt (i.e. When facing outward from the U-bend). Maximum attack depth into the metal such as penetration along the grain boundaries also varies a great deal with location and sometimes appears to be slightly greater with the sodium blend. However, as illustrated in the micrographs of corrosion scales formed on two typical specimen cross-sections obtained with $62 \mathrm{Li} / 38 \mathrm{~K}$ and $60 \mathrm{Li} / 40 \mathrm{Na}$ melts after 3000 hours of testing (cf. Figure 5.3), these depths of attack showing the maximum differences in oxide penetration are rather insignificant.

This now completes the corrosion testing for this program. The fact that melt composition does not appear to significantly affect corrosion with respect to the superior $310 s$ alloy, therefore, allows the elimination of one previously perceived important factor in electrolyte optimization, leaving ivio dissolution the only primary screening test. 


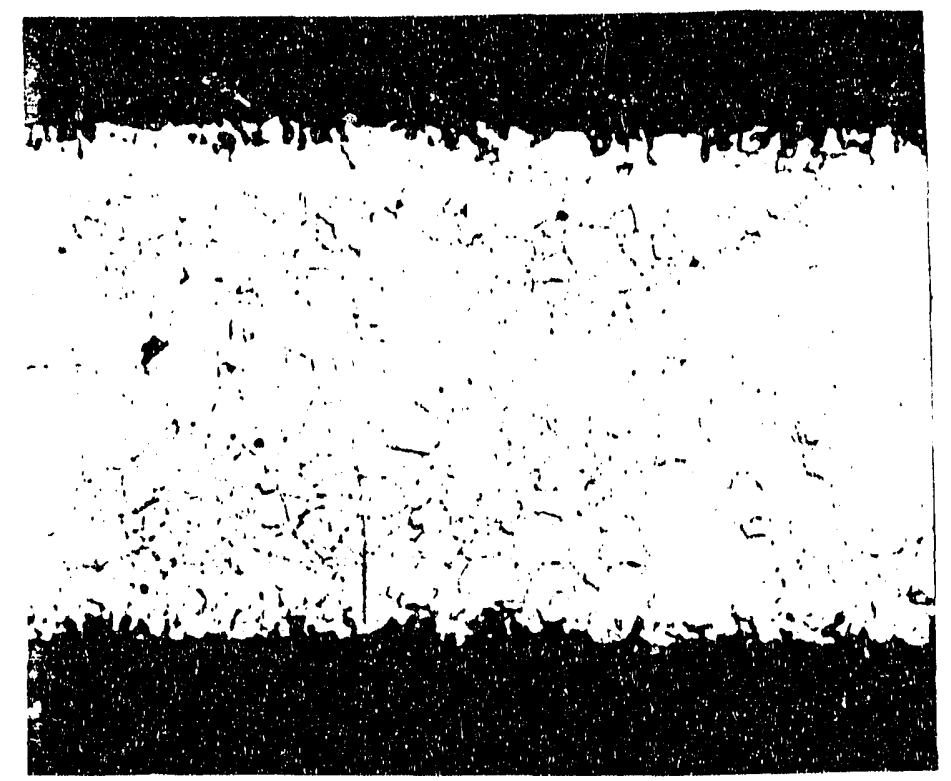

$(62 \mathrm{Li} / 3 \mathrm{BK}) \mathrm{CO}_{3}$
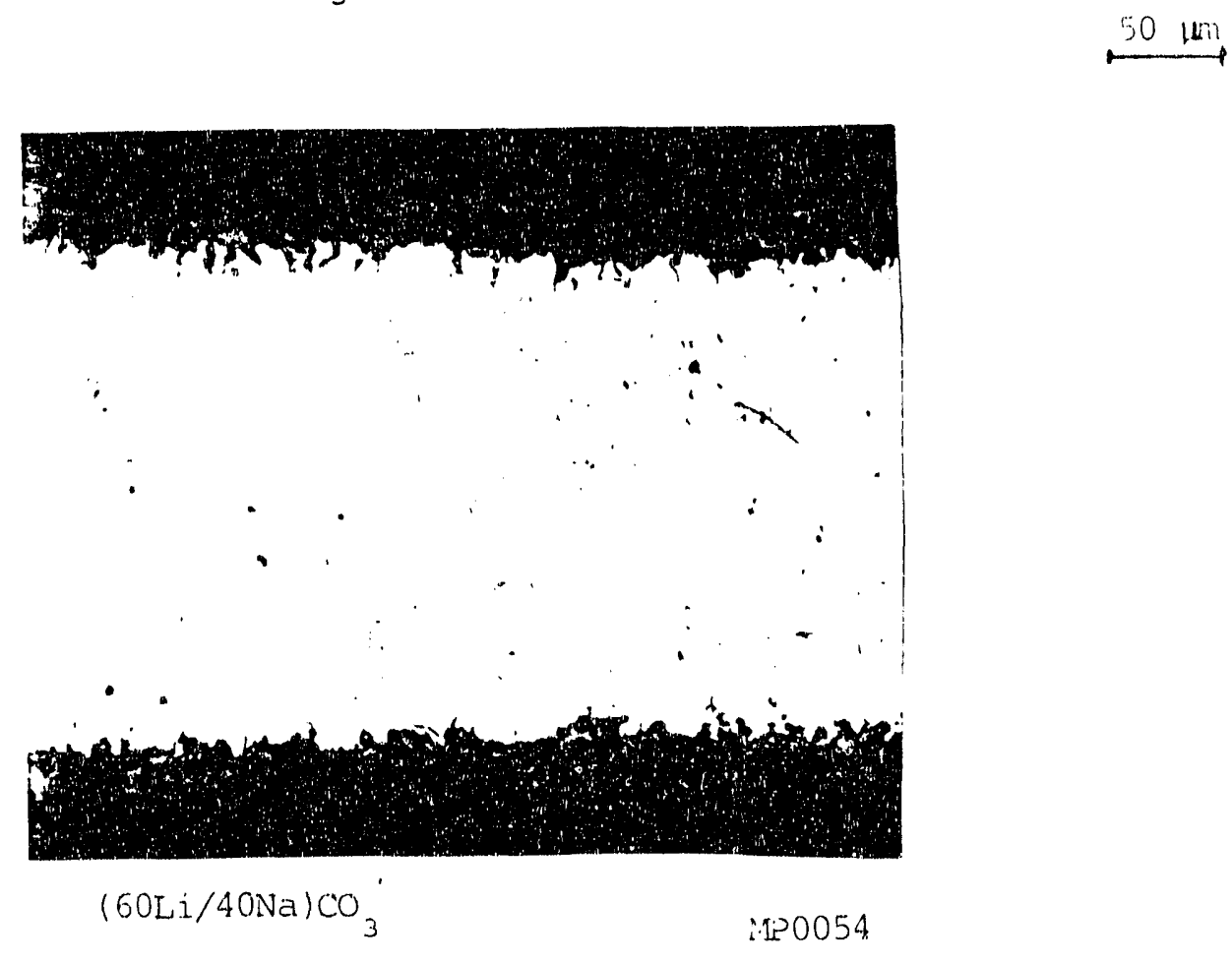

FIGURE 5.3 TYPICAL CCRROSION OF 31.0S IN TWO ELECTROLYTES $\left(700^{\circ} \mathrm{C}, 3000\right.$ hours) 


\subsection{NiO DISSOLUTION}

During this reporting period, Nio-dissolution experiments in 5 candidate melts (in duplicate) were also being completed. The melt samples from the pottests, after dissolution in $\mathrm{HCl}$, were all analyzed by the high sensitivity technique of Atomic Emission spectroscopy using an Inductively coupled plasma (ICP) to excite the spectral lines. The Nio solubilities were accentuated by performing two test series using an $85 \%$ CO2 atmosphere with results as illustrated in Table 5.1. The solubility measured in the $72 \mathrm{Li} / 28 \mathrm{~K}$ melt $\left(\mathrm{S}_{L}\right)$ shows that a substantial improvement may be obtained over the standard melt (S) by an increase in the more alkaline lithium content of a melt. This is about equivalent to the small alkaline earth additions that were also tested, but does not equal the very low solubility obtainable in $60 \mathrm{Li} / 40 \mathrm{Na}$ melt $\left(\mathrm{N}_{\mathrm{L}}\right)$. According to these results, Nio solubility decreases in the sequence $S>S_{X}>S_{L}>S_{M}>N_{L}$. It is interesting to note that the addition of $\mathrm{BaCO}_{3}$, even at a much higher solution level, is not as effective in suppressing Nio dissolution as the addition of MgCn3. This is consistent with the salt dissociation constants which show that the latter additive is the more basic alkaline earth carbonate.

TABLE 5.1

N.iO SOLUBILTTY OF CANDIDATE MELT'S AT $650^{\circ} \mathrm{C}$

\begin{tabular}{|c|c|c|c|}
\hline \multirow[t]{2}{*}{ Code } & \multirow[t]{2}{*}{ Electrolyte } & \multicolumn{2}{|c|}{$\begin{aligned} \text { Solubility in } & 85 \% \mathrm{CO} 2 \text {-Atmosphere } \\
& (\text { wppm) }\end{aligned}$} \\
\hline & & Test Series No. 1 & Test Series No. 2 \\
\hline$S$ & $62 \mathrm{Li} / 38 \mathrm{~K}$ & $19 \pm 4$ & $20 \pm 5$ \\
\hline $\mathrm{S}_{\mathrm{L}}$ & $72 \mathrm{Li} / 28 \mathrm{~K}$ & $11 \pm 3$ & $10 \neq 2$ \\
\hline $\mathrm{N}_{\mathrm{L}}$ & $60 \mathrm{Li} / 40 \mathrm{Na}$ & $8 \pm 1$ & $6 \pm 1$ \\
\hline$S_{M}$ & $\mathrm{Li} / \mathrm{K}+0.5 \mathrm{Mg}$ & $10 \dot{x} 2$ & $3 \pm 2$ \\
\hline $\mathrm{Sx}$ & $\mathrm{Li} / \mathrm{K}+5 \mathrm{Ba}$ & $16=3$ & $12+2$ \\
\hline
\end{tabular}




\subsection{CATHODE PERFORMANCE}

Preliminary results reported earlier showed that a large low-frequency loop existed which was apparently caused by some high impedance, mass transfer process. Such results were not consistent with what has been reported(16), and was felt to be due to configurational problems of poor gas access to the Nioelectrode, difficulties with non-uniform temperature distribution in the furnace, and also uneven electrolyte distribution between the two Nio-electrodes in the test package. Therefore, the test configuration was modified to allow better gas access to the measured cathodes and a flexible thermocouple was inserted in the upper gas distribution/current collector for more accurate control of the temperature.

It has also been frequently reported that the level of electrolyte fill has a strong effect on cathode performance. Hence uniform and suffictent electrolyte distribution is an important factor to insure accuracy in this type of study. The initial cathode fill-levels used were $25 \%$ of electrode porosity, which may have been too low as a result of the considerable electrolyte creepage as well as some of the corrosion which appeared to have occurred. Future experiments will start with carefully controlled, uniformly distributed, $40 \%$ carbonate-impregnated, Nio cathodes.

\subsection{LIALO2 STABILITY}

Two duplicate sets of LiAloz-stability tests, being obtained in both oxidant and in fuel atmosphere for three candidate melts, were started during the last quarter period and have now been completed. The electrolyte matrix tapes used are of standard ERC composition and are filled in-situ with the candidate electrolytes after the organic binders are burned out in the test chamber in the same manner as would happen during start-up of a fuel cell. 
ENERGY RESEARCH CORPORATION

The electrolyte quantities that fill these matrices are initially always contained in the electrodes which contact the tape. A number of the test samples, together with the original LiAlOz powder, a dry burned-out tape, and a o-hour carborate-filled sample, have been sent to Foote Minerals Company which is assisting with the complete characterization and analysis of the LiAlOz matrix materials.

\subsection{ELECTROLYTE MIGRATION}

Initial experiments for the electrolyte migration testing are in progress. The two alumina blocks which compress a gasket sample within the test rig have been cut and holes have been drilled in the end sections. A standard fibrous zroz gasket, impregnated with zroz-powder to reduce porosity, is being used in these migration studies. For initial testing, the filled $\mathrm{ZrO} 2$ gasket is sandwiched between the two alumina blocks and compressed to a final thickness of $30 \mathrm{mils}$ (from an initial thickness of $\sim 50 \mathrm{mils}$ ). Carbonate powder is then heaped around the gasket and the whole assembly is pre-treated at $650^{\circ} \mathrm{C}$ to allow the carbonate to melt and completely absorb in the porous gasket. The assembly is now being tested with different melts for evaluation of this filling procedure. Actual experimental runs are expected to start during the next reporting period.

\subsection{IN-CELL TESTING}

All Ni/Al anode and Ni cathode plaques as well as LiAlO2 matrix tapes for the eight bench-scale cell tests have been fabricated. The $310 \mathrm{~s}$ (cathode) and $316 \mathrm{~L}$ (anode) cell frames have been machined and the inside of the anode frames have been electrolyticaily nickel-plated. Some unexpected difficulties were initially encountered with the plating in that the coatings were too thin and of poor quality. These coatings have now been stripped and re-plating as well as all other surface treatments for wet seal protection, etc. are now being completed. 
Test stations are also being modified to replace the former on-off temperature controllers by PID controllers which apply the heater currents in a more even manner. This derelopment is expected to substantially reduce thermal distortion in the cell's end frames during operation and thus eliminate excessive load fluctuations which in the past were caused by a loss of contact. This improvement is expected to provide a more consistent picture of instantaneous cell behavior. An additional safety device has also been installed at each test station allowing all cells to be simultaneously put on OCV when unexpected problems occur such as any kind of power outage or gas supply breakdown even if it could cause just one of the celis to run at an excessively low voltage. Thus, it will guarantee that all cells at all times are operated under exactly the same regime of load or open circuit conditions in case any problems occur at night or over the weekends. Multipoint recording is also being used to constantly monitor cell voltage, current, temperatures on all cells, preheaters a. d humidifiers, and also pressure drops on all four cells.

Single cell testing with the $62 \mathrm{Li} / 33 \mathrm{~K}$ and $60 \mathrm{Li} / 40 \mathrm{Na}$ electrolytes will be started as soon as all final preparatory steps, quality control and the precision assembly of the cells is completed. 
REFERENCES (continuation)

(16) Yuh, C.Y., "Potential Relaxation and AC-Impedance of Porous Electrodes," Ph.D. Thesis, Illinois Institute of Technology, Chicago, IL. (1985).

(66) Shores, D.A., "The basicity of Binary Mixtures of Molten Alkali Carbonates," Extended Abstracts 87-2 (No. 192), The Electrochemical Society, Pennington, NJ (1987).

(67) Uchida, I., and Nishina, T., "Potential vs. po= Diagrams of the Oxygen Electrode in Molten Carbonates," Extended Abstracts 87-2 (No. 195), The Electrochemical Society, Pennington, NJ (1987).

(68) Twase, Y., Takevchi, M., Okada, H., and Hishinuma, Y., "Application of Impedance Measurement using FFT Analyzer in the study of Cathode Reactions of Molten Carbonate Fuel Cells," Extended Abstracts 87-2 (No. 196).

(69) Ogawa, T., Ohzu, H., Murata, K. and Shirogami, T., "Effect of Alkaline-Earth Carbonate Addition on Reduction of Nio Cathode Dissolution in Molten Carbonate Fuel Cells," Extended Abstracts 87-2 (No. 193), The Electrochem. Society, Pennington, NJ. (1987).

(70) Sato, K., Nishimura, T., Kimura, H., Urushibata, H. and Murahashi, T., "Interaction of LiAlO2 with stable and Metastable Phases of Molten Li2 $\mathrm{CO}_{3}-\mathrm{K}_{2} \mathrm{CO}_{3}, "$ Extended Abstracts 87-2 (No. 200), The Electrochemical Society, Pennington, NJ. (1987). 
ENERGY RESEARCH CORPORATION

(71) Ota, K., Shinjo, T., Mitsushima, S. and Kamiya, K., "The Solubility of Nickel Oxide and Nickel Ferrite in Molten Carbonate," Extended Abstracts 87-2 (No. 194), The Electrochemical Society, Pennington, NJ. (1987).

(72) Hsu, H.S., Devan, J.H. and Howell, M., "Equilibrium Solubilities of $\mathrm{LiFeO} 2$ and $(\mathrm{Li}, \mathrm{K}) 2 \mathrm{CrO}_{4}$ in Molten Alkali Carbonates at $650^{\circ} \mathrm{C}, "$ Technic al Report to U.S. Department of Energy under Contract DE-AC05-840R21400, Oak Ridge National Laboratory (August 1.986). 


\section{DISTRIBUTION}

A. U.S. Department of Energy Morgantown Energy Technology Center ATIN. W.J. Huber (COTR) 3610 Collins Ferry Road Morgantown, WV. 26507-0880

B. U.S. Department of Energy Morgantown Energy Technology Center ATTN. Contractor Reports Receipt Coordinator $\mathrm{M} / \mathrm{S} 105(\mathrm{~T}-44)$

3610 Collins Ferry Road

Morgantown, WV. 26507-0880

C. Argonne National Laboratory ATTN. John Young (Program Monitor) 9700 South Cass Avenue Argonne, IL. 60439 
DATE

FILMED

8131192 
